\title{
Effect of Browsing on the Growth of Jojoba Seedlings in the Dry-Lands of Kenya
}

\author{
Shadrack Kinyua Inoti \\ Egerton University, PO Box 536-20115, Egerton 20115, Kenya
}

\begin{abstract}
Jojoba is a desert shrub, introduced in the marginal areas of Kenya during 1980s. Jojoba domestication is being faced by browsing problems due to pastoralism in these areas. Massive browsing of leaves lowers photosynthesis leading to decline in plant functions. An experiment was set up in Maungu, with the aim of determining the effect of browsing on jojoba seedlings. The experimental design was a randomized complete block design with three treatments replicated three times. The treatments consisted of varying levels of browsing as follows: non browsed, $50 \%$ browsed and fully browsed. Seedlings were raised for six months before sampling. Variables assessed were: survival, height, root-collar diameter, leaf size, root length and number, internode length, sprout number, root/shoot ratio and total biomass. ANOVA was performed to determine differences among the treatments whilst significant differences among the means were separated using least significant difference (LSD) at $p \leq 0.05$. Results showed fully browsed seedlings were significantly lower in height $(26.2 \mathrm{~cm})$, internode length $(9.7 \mathrm{~mm})$, leaf length $(18.3 \mathrm{~mm})$ and width $(10.4 \mathrm{~mm})$ and total fresh plant biomass $(11.0 \mathrm{~g})$ compared to the non browsed ones which showed $31.1 \mathrm{~cm}, 23.2,36.1$ and $16.6 \mathrm{~mm}$ and $17.8 \mathrm{~g}$, respectively. On the other hand, fully browsed seedlings showed significantly higher root/shoot ratio. Seedling growth was negatively affected by severity of browsing which resulted in stunted growth. The study recommended that browsing of seedlings should be prevented since it hinders plant growth.
\end{abstract}

Key words: Browsing level, growth, jojoba, tree seedling.

\section{Introduction}

Over $80 \%$ of Kenya is composed of arid and semi arid lands (ASALs) with only a few crops being grown mainly for subsistence purposes [1]. They experience frequent drought leading to crop failure hence overdependence on food relief [2]. These ASALs are fragile ecosystems with their productivity being threatened by various factors such as overgrazing, deforestation, land degradation and harsh climate $[3,4]$. Jojoba domestication is being faced by problems of browsing from both livestock and wildlife which are the major activities in the ASALs. Increasing human population has resulted to migration into fragile marginal lands causing higher livestock stocking triggering severe land degradation [5].

Jojoba (Simmondsia chinensis L. Schn.) is a high

Corresponding author: Shadrack Kinyua Inoti, Ph.D., research fields: agroforestry, forest biology and arid land forestry. value shrub growing in the arid areas [6] and it is a promising cash crop for the arid-lands throughout the world. It grows on coarse, light and medium textured well drained sandy soils with marginal fertility and acidic to alkaline $\mathrm{pH}$ of 5-8 [7]. It tolerates low rainfall (220-400 $\mathrm{mm} /$ year) and high temperature range $\left(0-54{ }^{\circ} \mathrm{C}\right)$. Jojoba produces nuts with $45 \%-55 \%$ of its weight as oil. It has varied uses ranging from edible oils, lubricants, cosmetics and medicines [8, 9].

Browsing of tree seedlings by wildlife can reduce height growth, stem and foliage density resulting to a more open understory [10]. Recent studies by Foster [11] described that defoliation of trees by herbivores as a biological disturbance that reduces the leaf area and causes the trees to change their growth patterns and produce defense chemicals [12] as a survival strategy. However, faster growing species have significant reduction in carbohydrate concentration due to browsing followed by relatively faster recovery 
[13]. Mature jojoba bushes are frequently stunted to a low height of up to $1 \mathrm{~m}$ due to the harshness of climate and browsing by wildlife and livestock [14], although they can attain up to $2 \mathrm{~m}$ in height. However, during the wet season, other fodder species are available for browsers hence minimal damage occurs in jojoba. The objective of the study was to determine the effect of browsing on the growth of jojoba seedlings in dry-lands.

\section{Materials and Methods}

\subsection{Study Site}

The trial was set up in Voi, Kenya, where jojoba bushes are established, along longitude $37^{\circ} 40^{\prime} 60^{\prime \prime}$ to $38^{\circ} 35^{\prime} 25^{\prime \prime} \mathrm{E}$ and latitude $3^{\circ} 23^{\prime} 60^{\prime \prime}$ to $3^{\circ} 24^{\prime} 26^{\prime \prime} \mathrm{S}$ at an altitude of $892 \mathrm{~m}$ above the sea level [15].

The area is located in semi arid environment characterized by wooded scattered trees, shrubs and grasses with pastoralism and wildlife as the major activity. A bimodal rainfall distribution of $596 \mathrm{~mm}$ annually is received. Temperatures range from $16^{\circ} \mathrm{C}$ to $37{ }^{\circ} \mathrm{C}$ with an average of $26^{\circ} \mathrm{C}$ and moderate high humidity $(60 \%-80 \%)$ [16]. However, the area has frequent droughts due to climate change leading to dependence on famine relief food.

\subsection{Experimental Design}

The nursery experiment was laid down in a randomized complete block design with three treatments replicated three times. The treatments consisted of jojoba seedlings at varying levels of browsing as follows: non browsed, $50 \%$ browsed and fully browsed. Seedlings were raised for a period of six months from January to June 2013 and treatments were introduced at three months growth. Seedlings were raised in medium sized pots of $12.5 \mathrm{~cm}$ width and $20 \mathrm{~cm}$ length. The potting media was sand and farmyard manure in the ratio 2:1, respectively. Each replicate consisted of three rows with 10 plants.

\subsection{Data Collection}

Six month old jojoba seedlings were sampled after treatment application for a period of three months. Three plants were then sampled per row. Variables assessed were: survival, plant height, root collar diameter, leaf size, root length and number, internode length, number of sprouts, root to shoot ratio and total fresh plant biomass.

\subsection{Data Analysis}

ANOVA was performed using SAS [17] to determine differences among the treatments. The significant differences among the means of variables were separated using least significant difference (LSD) at $p \leq 0.05$.

\section{Results and Discussion}

\subsection{Effect of Browsing on Survival and Shoot Growth of Jojoba Seedlings}

Shoot growth of jojoba seedlings was severely affected by browsing leading to stunted growth. Results of the current study showed that fully browsed seedlings were significantly $(p \leq 0.05)$ lower in plant height $(26.2 \mathrm{~cm})$, internode length $(9.7 \mathrm{~mm})$ and total fresh plant biomass $(11.0 \mathrm{~g})$ compared to the non browsed ones which showed $31.1 \mathrm{~cm}, 23.2 \mathrm{~mm}$ and $17.8 \mathrm{~g}$, respectively (Table 1). The findings are consistent with earlier studies by Gill and Beardall [10] who reported that browsing of tree seedlings by wildlife tend to limit height growth, reduce stem and foliage density resulting to a more open understory.

Mature jojoba bushes are frequently stunted to a height of $60 \mathrm{~cm}$ to $90 \mathrm{~cm}$ by the harshness of climate and also heavy browsing by wildlife and livestock due to their high palatability and nutritive value [14], although they can attain up to $2 \mathrm{~m}$ in height [7]. According to Refs. [8, 10, 18, 19], browsing reduces lower branching and abundance of species but does not affect stem diameter. However, Horsley et al. [20] reported 
Table 1 Effect of browsing level on survival and shoot growth of jojoba seedlings.

\begin{tabular}{llllll}
\hline Browsing level & Survival $(\%)$ & Plant height $(\mathrm{cm})$ & $\begin{array}{l}\text { Internode length } \\
(\mathrm{mm})\end{array}$ & Number of sprouts & $\begin{array}{l}\text { Total fresh plant } \\
\text { biomass }(\mathrm{g})\end{array}$ \\
\hline Non browsed & 66.7 & $31.1 \mathrm{a}$ & $23.2 \mathrm{a}$ & $1.2 \mathrm{~b}$ & $17.8 \mathrm{a}$ \\
$50 \%$ browsed & 60.0 & $28.2 \mathrm{ab}$ & $15.6 \mathrm{ab}$ & $3.7 \mathrm{~b}$ & $13.6 \mathrm{~b}$ \\
Fully browsed & 63.3 & $26.2 \mathrm{~b}$ & $9.7 \mathrm{~b}$ & $12.5 \mathrm{a}$ & $11.0 \mathrm{~b}$ \\
CV & 40.8 & 5.9 & 23.1 & 28.1 & 9.7 \\
LSD & 58.5 & 3.8 & 8.5 & 3.7 & 3.1 \\
\hline
\end{tabular}

Means with similar letters in each column are not significantly different using least significant difference (LSD) at $p \leq 0.05$.

that browsing resulted to shorter heights and thinner diameters.

Similarly, fully browsed seedlings showed 1.6 times lower total fresh plant biomass compared to non browsed seedlings. This shows that the former seedlings depicted stunted shoot growth. This corroborates with findings by Rooney and Waller [21] who reported that defoliation and leaf height reduced relative growth rate over short time periods. Work by Li et al. [22] observed that the leaf edge removal resulted in significantly reducing the total plant and root biomass.

Previous results by Ferraro and Oesterheld [23] reported negative effect of defoliation on plant growth and variability in the defoliation responses of different plant components. There was also an intermediate negative effect on total production. However, Roundy et al. [24] reported that moderate browsing pressure resulted in forage yields similar to those of non browsed plants which is contradictory to the present study but they further observed that heavy browsing greatly reduced shrub size and forage yield which agrees with this study. Studies by Ives and Nairn [25] found that partial defoliation reduced initial growth in young tamarack (Larix laricina) trees.

Intensity of mammalian browsing may modify the magnitude and the direction of tree diversity effects on tree growth and susceptibility to insect herbivory [26, 27]. Unbrowsed trees experienced lower insect chewing damage in mixed stands whilst browsed trees suffered more insect chewing damage in diverse stands. Low levels of persistent insect damage $(<2 \%)$ have been shown to reduce birch growth and fitness
[28]. Thus, the effects of browsing on tree growth may be further compounded by increases in background insect herbivore damage. Growth of moderately browsed trees increased with tree species richness, but growth of severely browsed birch trees was unaffected [27].

As browsing intensity increases, both upright and lateral shoots are usually removed resulting to reduced vertical and horizontal growth [29, 30] and thereby reducing the competitive ability of trees. Similarly, severely browsed trees are more likely to suffer from stem breakage by moose, which reduces tree height and hinders growth [31]. These findings are consistent with the findings of the current study despite the fact that the authors considered mature trees as opposed to seedlings in the present study.

However, the number of sprouts was significantly ( $p \leq 0.05$ ) higher for fully browsed seedlings compared to the non browsed and partially (50\%) browsed seedlings and could be explained by compensatory strategy by the severely browsed seedlings through resprouting. This is in agreement with earlier studies by Roundy and Dobrenz [32] who stated that new twigs were initiated from lateral buds to compensate for the loss of apical buds and twigs from herbivory. Similarly, McNaughton [33] reported that lightly defoliated plants may increase sufficiently in biomass through overcompensation to end up larger in mass than non-defoliated controls. Branches in heavily browsed areas usually take longer to grow if the apical meristem has been removed through browsing [34].

Earlier findings by Ferraro and Oesterheld [23] 
reported that defoliation intensity had no effect on response to defoliation which is contradictory to the present study. Defoliated larch and pine seedlings showed less biomass and starch component than those not defoliated [35]. However, both species showed overcompensation in total and component biomass in seedlings defoliated by $25 \%$ but generally defoliation caused about a 50\% decrease in whole-seedling starch concentration. Further studies by Atkinson et al. [13] reported that faster growing species showed significant carbohydrate reduction after browsing but this was followed by fast recovery. Rates of photosynthesis on foliage regrowth increased relative to non-defoliated controls [36]. In addition, plant biomass is not necessarily reduced by the same percentage as leaf area [37].

Heavily browsed trees take less energy into somatic growth but instead divert more energy into forming secondary compounds which might be toxic and hence deter herbivory $[38,39]$. High stress levels cause the energy of plants to be focused towards stem development but less branch growth [40]. Studies in Northern Michigan by Rudolph and Autenrieth [41] reported that deer population changes with seasons and their population increases alongside with increase in nutrient availability. Trees invest most of their energy into growing leaves towards the top canopy since this portion receives direct sunlight and these leaves are the most efficient in photosynthesis [42]. Trees above the browsing height are able to obtain sufficient nutrients to increase tree girth regardless of browsing [43].

\subsection{Effect of Browsing on Root and Foliage Growth of Jojoba Seedlings}

On the other hand, fully browsed seedlings also showed significantly $(p \leq 0.05)$ lower growth in leaf length $(18.3 \mathrm{~mm})$ and width $(10.4 \mathrm{~mm})$ compared to non browsed seedlings which were $36.1 \mathrm{~mm}$ and 16.6 $\mathrm{mm}$, respectively (Table 2). Seedling growth was negatively correlated with severity of browsing which resulted in short internodes and small leaf sizes. These findings are in agreement with recent studies by Foster [11] and Gruning et al. [12] who stated that defoliation affects tree performance by reducing leaf area leading to low photosynthetic capacity and nitrogen cycling in the forest ecosystem.

Fully browsed seedlings showed significantly higher root to shoot ratio and number of lateral roots, although the latter was not significant, compared to non browsed ones. This shows that root growth in terms of length and also number of lateral roots are least affected by browsing and this leads to a significantly higher root to shoot ratio for the browsed seedlings. The findings of the current study corroborate with earlier studies by Ferraro and Oesterheld [23] who reported that defoliation causes minimum effect on root growth especially root biomass.

According to Pinoyfarmer [44], jojoba seedlings can attain root length 10 times the shoot height with a growth rate of $2.5 \mathrm{~cm}$ per day making them to possess special deep root system adaptation for arid lands. However, further studies by Li et al. [22] reported that

Table 2 Effect of browsing level on root and leaf growth of jojoba seedlings.

\begin{tabular}{lllllll}
\hline Browsing level & $\begin{array}{l}\text { Root collar } \\
\text { diameter }(\mathrm{mm})\end{array}$ & Root length $(\mathrm{cm})$ & Number of roots & $\begin{array}{l}\text { Root to shoot } \\
\text { ratio }\end{array}$ & Leaf length (mm) Leaf width (mm) \\
\hline Non browsed & $5.1 \mathrm{~b}$ & 32.4 & 47.4 & $1.03 \mathrm{~b}$ & $36.1 \mathrm{a}$ & $16.6 \mathrm{a}$ \\
$50 \%$ browsed & $6.0 \mathrm{a}$ & 33.2 & 59.0 & $1.03 \mathrm{~b}$ & $26.6 \mathrm{ab}$ & $12.7 \mathrm{ab}$ \\
Fully browsed & $5.1 \mathrm{~b}$ & 33.8 & 64.2 & $1.30 \mathrm{a}$ & $18.3 \mathrm{~b}$ & $10.4 \mathrm{~b}$ \\
CV & 5.9 & 9.5 & 15.5 & 3.0 & 17.2 & 17.7 \\
LSD & 0.7 & 7.1 & 20.0 & 0.08 & 10.5 & 5.3 \\
\hline
\end{tabular}

Means with similar letters in each column are not significantly different using LSD at $p \leq 0.05$. 
removal of leaf edges changed the carbon allocation resulting in reduced root development which further hinder nutrient uptake by plants from the soil leading to stunted growth. More recent research by Foster [11] also stated that evergreen trees are more prone to death after defoliation because most of the food storage is in the foliage while deciduous ones store their carbohydrates in the stem and roots.

\section{Conclusions}

Seedling growth was negatively affected by severity of browsing which resulted in lower plant height, short internodes and small leaf sizes leading to stunted growth.

\section{Recommendations}

The study recommended that browsing of jojoba seedlings should be prevented through fencing since it severely hinders plant growth which can also further slow down field establishment. Further research needs to be carried out to explore the possibilities of replacing the severely browsed seedlings with newly replanted ones since the former take a long time to recover.

\section{Acknowledgments}

The author wishes to sincerely thank Wildlife works for supporting this research in terms of materials and funding and also Egerton University for giving time off to perform the research.

\section{References}

[1] KARI. 2009. Kenya Agricultural Research Institute Strategic Plan 2009-2014. Nairobi, Kenya: KARI, 107.

[2] Barrow, E. G. C. 1996. The Drylands of Africa: Local Participation in Tree Management. Nairobi, Kenya: Initiative publishers, 268.

[3] Weiss, E. 1986. Plants Tolerant of Arid and Semi Arid Conditions: Their Nomenclature and Potential Uses. Ministry of Agriculture and Livestock Development, Nairobi, Kenya.

[4] Dixon, J. A., James, E. D., and Sherman, P. B. 1998. The Economics of Dryland Management. Earth Scans
Publications, HD, London, UK.

[5] Rowland, J. R. J. 1993. Dryland Farming in Africa. London: MacMillan Press Ltd, 336.

[6] National Academy of Sciences (NAS). 1974. More Water for Arid Lands: Promising Technologies and Research Opportunites. National Academy of Sciences, Washington, DC. USA, 165.

[7] Undersander, D. J., Oelke, E. A., Kaminski, A. R., Doll, J. D., Putnam, D. H., Combs, S. M., and Hanson, C. V. 1990. Alternative Field Crop Manual. University of Wisconsin-Madison and Minnesota, St. Paul, USA, 48.

[8] Hogan, I., and Bemis, W. P. 1983. "Buffalo Gourd and Jojoba: Potential New Crops for Arid Lands.” Advances in Agronomy 36: 317-49.

[9] Amarger, V., and Mercier, L. 1996. "Nuclear Ribosomal DNA Unit Length Variation: A Putative Marker of Genetic Diversity in Jojoba." International Journal of Plant Science 157 (3): 296-302.

[10] Gill, R. M. A., and Beardall, V. 2001. "The Impact of Deer on Woodlands: The Effects of Browsing and Seed Dispersal on Vegetation Structure and Composition." Forestry 74 (3): 209-18.

[11] Foster, J. R. 2017. "Xylem Traits, Leaf Longevity and Growth Phenology Predict Growth and Mortality Response to Defoliation in Northern Temperate Forests." Tree Physiology 37 (9): 1151-65.

[12] Gruning, M. M., Simon, J., Rennenberg, H., and I-M-Arnold, A. 2017. "Defoliating Insect Mass Outbreak Affects Soil N Fluxes and Tree N Nutrition in Scots Pine Forests." Front Plant Sci. 8: 954.

[13] Atkinson, R. R. L., Burrel, M. M., Rose, K. E., Osborne, C. P., and Rees, M. 2014. "The Dynamics of Recovery and Growth: How Defoliation Affects Stored Resources." Proceedings of the Royal Society B: Biological Sciences 281 (1783). doi: 10.1098/rspb.2013.3355.

[14] Nord, E. C., and Kadish, A. 1974. "Simmondsia chinensis (Link) C. K. Schneid. Jojoba.” In Seeds of Woody Plants in the United States, edited by Schopmeyer, C. S. Agriculture Handbook No. 450. Washington, DC: U.S. Department of Agriculture, Forest Service, 774-6.

[15] Taita Taveta District Strategic Plan (TTDSP). 2008. "Ministry of State for Development of Northern Kenya and Other Arid Lands." Accessed October 22, 2018. http://erepository.uonbi.ac.ke/bitstream/handle/11295/613 10/Ednah.

[16] Thagana, W. M., Riungu, T. C., and Inoti, S. K. 2003. Report on Jojoba (Simmondsia chinensis) Cultivation in Kenya. KARI, Njoro, 10.

[17] Statistical Analytical System (SAS). 1996. SAS/STAT 9.2 User's Guide. Cary N.C.: SAS Institute Inc. Accessed October 22 , 2018. 
http://support.sas.com/documentation/cdl/en/statugintrod uction/61750/PDF.

[18] Garthe, A., Kissel, L., Machcinski, E., and Lau, P. 2014. "The Impact of Deer Browsing on Tree Growth, Plant Biomass and Biodiversity.” Deep Blue. Accessed July 22, 2017. http://deepblue.lib.umich.edu/handle/2027.42.

[19] Anderson, R. C. 1994. "Height of White Flowered Trillium (Trillium grandiflorum) as an Index of Deer Browsing Intensity." Ecological Applications 4 (1): 104-9.

[20] Horsley, S. B., Stout, S. L., and DcCalesta, D. S. 2003. "White Tailed Deer Impact on the Vegetation Dynamics of a Northern Forest." Ecological Applications 13 (1): 98-118.

[21] Rooney, T. P., and Waller, D. M. 2001. "How Experimental Defoliation and Leaf Height Affect Growth and Reproduction in Trillium grandiflorum." Journal of the Torrey Botanical Society 128 (4): 393-9.

[22] Li, W., Luo, J., Tian, X., Peng, C., and Zhou, X. 2012. "Patterns of Defoliation and Their Effect on the Plant Growth and Photosynthetic Characteristics of Ipomoea cairica." Weed Biology and Management 12 (1): 40-6.

[23] Ferraro, D. O., and Oesterheld, M. 2002. "Effect of Defoliation on Grass Growth: A Quantitative Review." Oikos 98 (1): 125-33.

[24] Roundy, B. A., Ruyle, G. B., and Dobrenz, A. K. 1987. "Growth, Nutrient, and Water Status of Jojoba (Simmondsia chinensis) in Relation to Livestock Grazing." In Proceedings of Symposium on Plant-Herbivore Interactions, edited by Provenza, F. D., Flinders, J. T., and McArthur, E. D. Snowbird, UT. Gen. Tech. Rep. INT-222. Ogden, UT: U.S. Department of Agriculture, Forest Service, Intermountain Research Station, 146-53.

[25] Ives, W. G. H., and Nairn, L. D. 1966. "Effects of Defoliation on Young Upland Tamarack in Manitoba." Forestry Chronicle 42: 137-42.

[26] Cook-Patton, S. C., Laforgia, M., and Parker, J. D. 2014. "Positive Interactions between Herbivores and Plant Diversity Shape Forest Regeneration." Proceedings of the Royal Society B 281 (1783). doi: 10.1098/rspb.2014.0261.

[27] Muiruri, E. W., Milligan, H. T., Morath, S., and Koricheva, J. 2015. "Moose Browsing Alters Tree Diversity Effects on Birch Growth and Insect Herbivory." Functional Ecology 29: 724-35.

[28] Zvereva, E. L., Zverev, V., and Kozlov, M. V. 2012. "Little Strokes Fell Great Oaks: Minor but Chronic Herbivory Substantially Reduces Birch Growth." Oikos 121: 2036-43.

[29] Den Herder, M., Bergstrom, R., Niemela, P., Danell, K., and Lindgren, M. 2009. "Effects of Natural Winter Browsing and Simulated Summer Browsing by Moose on
Growth and Shoot Biomass of Birch and Its Associated Invertebrate Fauna." Annales Zoologici Fennici 46: 63-74.

[30] Speed, J., Austrheim, G., and Hester, A. 2013. "Regional-Scale Alteration of Clear-Cut Forest Regeneration Caused by Moose Browsing." Forest Ecology and Management 289: 289-99.

[31] Rea, R. 2011. "Impacts of Moose (Alces alces) Browsing on Paper Birch (Betula papyrifera) Morphology and Potential Timber Quality.” Silva Fennica 45: 227-36.

[32] Roundy, B. A., and Dobrenz, A. K. 1989. "Herbivory and Plant Water Status of Jojoba (Simmondsia chinensis (Link) Schn.) in the Sonoran Desert in Arizona.” Journal of Arid Environments 16: 283-91.

[33] McNaughton, S. J. 1983. "Compensatory Plant Growth as a Response to Herbivory.” Oikos 40: 329-36.

[34] Kribel, J. R., Kolman, K. B., and Ware, S. 2011. "Rapid Change in Sapling and Seedling Layers in an Otherwise Stable Hardwood Forest: An Effect of Deer Browsing." Castanea 76 (2): 140-8.

[35] Vanderklein, D. W., and Reich, P. B. 1999. "The Effect of Defoliation Intensity and History on Photosynthesis, Growth and Carbon Reserves of Two Conifers with Contrasting Leaf Lifespans and Growth Habits." New Phytol. 144: 121-32.

[36] Reich, P. B., Walters, M. B., Krause, S. C., Vanderklein, D. W., Raffa, K. F., and Tabone, T. 1993. "Growth, Nutrition and Gas Exchange of Pinus resinosa Following Artificial Defoliation.” Trees 7: 67-77.

[37] Bassman, J., Myers, W., Dickman, D., and Wilson, L. 1982. "Effects of Simulated Insect Damage on Early Growth of Nursery-Grown Hybrid Poplars in Northern Wisconsin." Canadian Journal of Forest Research 12: 1-9.

[38] Swain, T. 1977. "Secondary Compounds as Protective Agents." Annual Review of Plant Physiology 28 (1): 479-501.

[39] Robbins, C. T., Hanley, T. A., Hagerman, A. E., Hjeljord, O., Baker, D. L., Schwartz, C. C., and Mautz, W. W. 1987. "Role of Tannins in Defending Plants against Ruminants: Reduction in Protein Availability." Ecology 68 (1): 98-107.

[40] Stoengart, J., Picdade, M. T. F., Ludwigshausen, S., Horna, V., and Worbes, M. 2002. "Phenology and Stem Growth Periodicity of Tree Species in Amazonian Flood Plain Forests." Journal of Tropical Ecology 18 (4): 581-97.

[41] Rudolph, B., and Autenrieth, A. 2013. "Michigan Deer Hunting Prospects." Michigan Department of Natural Resources. Accessed September 9, 2017. http://www.michigan.gov/documents/dnr/deer hunting prospects 4358577.pdf. 
[42] Terjung, W. H., and Louie, S. S. 1973. "Energy Budget and Photosynthesis of Canopy Leaves." Annals of the Association of American Geographers 63 (1): 109-18.

[43] Hartnett, D. C., Ott, J. P., Sebes, K., and Ditlhogo, M. K. 2012. "Coping with Herbivory at the Juvenile Stage: Response to Defoliation and Stem Browsing in the Africa
Savanna Tree Colophospermum mopane." Journal of Tropical Ecology 28 (2): 161-9.

[44] Pinoyfarmer. 2007. "Jojoba: A Promising New Crop for Arid Lands and New Raw Materials for Industry." Accessed October 22, 2018. http://www.researchgate.net/profile/Arvin-Singh56/post. 